\title{
PENDIDIKAN ISLAM DALAM PERSPEKTIF ALIRAN KALAM: Qadariyah, Jabariyah, dan Asy'ariyah
}

\author{
M. Yunus Samad \\ STAI DDI Pinrang \\ Jl. Andreas Wahani No. 27 Pinrang \\ Email: staiddipinrang@yahoo.co.id
}

\begin{abstract}
Abstrak:
Bagaimana pun sederhananya peradaban suatu masyarakat, di dalamnya pasti berlangsung suatu proses pendidikan, sehingga sering dikatakan bahwa pendidikan telah ada sepanjang peradaban umat manusia. Proses pendidikan merupakan proses pengembangan segala potensi yang dimiliki manusia. Meskipun dalam Islam terdapat beberapa pandangan mengenai pendidikan Islam.Paham Qadariyah memandang proses pendidikan Islam dapat berlangsung dengan baik jika manusia bersungguh-sungguh berusaha dalam menanamkan nilai-nilai islami dalam kehidupannya. Paham Jabariyah memandang bahwa proses pendidikan tidak begitu berpengaruh sebab berhasil tidaknya sebuah proses pendidikan tersebut akan ditentukan oleh Allah. Sedangkan paham Asy'ariyah memandang pendidikan Islam merupakan proses yang dinamis, dalam artian manusia di samping telah memiliki potensi dasar untuk menerima proses pendidikan ia juga bergantung pada kepribadian seseorang.
\end{abstract}

\begin{abstract}
:
No Matter how simple a civilization of society is, there must be a process of education, therefore it is frequently said that education has existed throughout human civilization. The process of education is the process of developing the potential of every human being. In Islam there are several views on islamic education. The idea of Qadariyah views that Islamic education process can take place properly if the man earnestly try to instill Islamic values in his life. The idea of Jabariyah views that the education process is not so influential because the success or failure of an educational process will be determined by God. While the idea of Ash'ari views that Islamic education is a dynamic process, it means that human being not only has a basic potential to be educated but also they depend on their personality.
\end{abstract}

Kata kunci:

Pendidikan Islam, Qadariyah, Jabariyah, Asy'ariyah

\begin{abstract}
AL-QUR'AN merupakan kitab suci petunjuk yang senantiasa mengajak manusia untuk menuntut ilmu pengetahuan. Bahkan dalam salah satu ayat al-Qur'an Allah swt. Menjanjikan akan menempatkan orang-orang yang berpengetahuan pada derajat yang lebih tinggi. ${ }^{1}$ Demikian tegasnya Allah swt. memerintahkan kepada manusia sehingga mereka termotivasi untuk menuntut ilmu pengetahuan dan mengembangkannya dalam berbagai bentuk kreativitas. Orang yang memadukan ketinggian ilmu pengetahuan dan teknologi serta kedalaman iman dan takwa mendapatkan tempat yang sangat tinggi di sisi Allah swt. sebagaimana firman-Nya dalam QS alMujādilah/58 ayat 11:
\end{abstract}




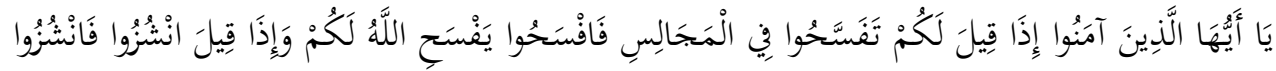

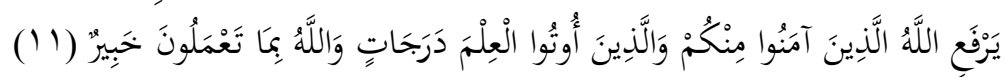

Hai orang-orang beriman apabila dikatakan kepadamu: "Berlapang-lapanglah dalam majlis", maka lapangkanlah niscaya Allah akan memberi kelapangan untukmu. Dan apabila dikatakan: "Berdirilah kamu", maka berdirilah, niscaya Allah akan meninggikan orang-orang yang beriman di antaramu dan orangorang yang diberi ilmu pengetahuan beberapa derajat. Dan Allah Maha Mengetahui apa yang kamu kerjakan. ${ }^{2}$

Ayat di atas yang berkaitan dengan kemuliaan yang dimiliki oleh orang yang beriman dan berilmu pengatahuan yaitu:

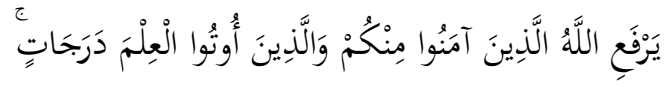

Dijelaskan dalam kitab “تفسير آيات الأحكام من القرآن" yang disusun oleh Muhammad Ali al-Syābūny tentang tafsir ayat tersebut bahwa sesungguhnya Allah mencintai hamba-Nya yang taat dan mengangkat derajat orang-orang yang beriman, ilmuan yang mengamalkan ilmunya serta orang-orang yang berbuat kebaikan karena Allah. Karena sesungguhnya ulama pewaris para nabi. ${ }^{3}$

Pendidikan dalam arti yang luas telah ditempatkan sebagai bagian dari misi Rasulullah yang utama dalam mengajarkan dan menyebarkan risalah yang diamanahkan Allah swt. Islam juga menegaskan bahwa proses pendidikan telah terjadi sejak awal adanya manusia di muka bumi ini.

Secara umum, pendidikan diartikan sebagai usaha manusia untuk membina kepribadiannya sesuai dengan nilai-nilai dan budaya masyarakat. ${ }^{4}$ Dengan demikian, bagaimana pun sederhananya peradaban suatu masyarakat, di dalamnya pasti berlangsung suatu proses pendidikan, sehingga sering dikatakan bahwa pendidikan telah ada sepanjang peradaban umat manusia.

Pendidikan Islam adalah pendidikan yang dilaksanakan berdasarkan pada ajaran Islam..$^{5}$ Karena ajaran Islam berdasarkan Alquran, sunnah, pendapat ulama serta warisan sejarah, pendidikan Islam pun mendasarkan diri pada Alquran, sunnah, pendapat ulama serta warisan sejarah tersebut. Pendidikan Islam memiliki visi yaitu membangun sebuah kehidupan manusia yang patuh dan tunduk kepada Allah serta membawa rahmat bagi seluruh alam. Pendidikan Islam diharapkan menghasilkan manusia yang berguna bagi diri dan masyarakatnya serta senang dan gemar mengamalkan ajaran Islam dalam berhubungan dengan Allah dan sesama manusia. Ia mengambil manfaat untuk kepentingan hidup di dunia dan kebahagiaan di akhirat. ${ }^{6}$

Berdasarkan hal tersebut dapat dipahami bahwa proses pendidikan merupakan proses pengembangan segala potensi yang dimiliki manusia. Meskipun dalam Islam terdapat beberapa pandangan mengenai pendidikan Islam, dalam hal ini pandangan Qadariyah yang memandang segala perbuatan yang dilakukan manusia merupakan hasil usahanya sendiri tanpa adanya intervensi dari Allah. Sedangkan pandangan Jabariyah yang memandang bahwa manusia tunduk pada kehendak Tuhan semata, be- 
gitupun dengan Asy'ariyah yang memandang bahwa Tuhan pencipta semua perkara manusia berarti Tuhanlah pembuat semuanya pula. Semua perbuatan yang timbul dari manusia dengan perantaraan daya yang diciptakan adalah berarti manusia sebenarnya merupakan tempat bagi perbuatan-perbuatan Tuhan.

\section{Rumusan Masalah}

Berdasar dari latar belakang masalah yang telah dikemukakan di atas mengenai pendidikan Islam dengan pandangan Qadariyah, Jabariyah dan Asyariyah maka penulis merumuskan beberapa permasalahan sebagai berikut:

1. Bagaimana pendidikan Islam dalam pandangan Qadariyah?

2. Bagaimana pendidikan Islam dalam pandangan Jabariyah?

3. Bagaimana pendidikan Islam dalam pandangan Asy'ariyah?

\section{PEMBAHASAN}

\section{Pendidikan Islam dalam Pandangan Qadariyah}

\section{Sejarah Singkat Paham Qadariyah}

Qadariyah pertama kali dimunculkan oleh Ma'bad al-Juhani dan Ghailan alDimasyqi. Ma'bad al-Juhani adalah seorang taba'i yang dapat dipercaya dan pernah berguru pada Hasan al-Basri. Adapun Ghailan al-Dimasyqi adalah seorang orator yang berasal dari Damaskus. Ma'bad al-Juhani menjadikan Irak sebagai daerah sasaran pengembangan paham ini dalam waktu yang lama, sedangkan Ghailan alDimasyqi mengembangkan di daerah Damaskus dan Syam.

Adapun corak pemikiran paham Qadariyah lebih mengedepankan sikap rasionalitas, otoritas akal yang sangat berperan dalam segala perbuatan atau aktivitas manusia tanpa adanya campur tangan Tuhan. Dalam filsafat, paham Qadariyah disebut paham indeterminisme sebagai lawan determinisme (Jabariyah). Paham indeterminisme memiliki beberapa argumen yang membuktikan kebebasan kehendak manusia dalam berbuat, antara lain:

1. Kehendak merupakan salah satu bentuk keinginan. Sebagai umumnya, keinginan, kehendak itu mempunyai tujuan tertentu dan karena itu menghendaki terjadinya tindakan untuk mencapainya.

2. Keinginan merupakan suatu tindak lanjut dari pengetahuan, dengan demikian kehendak itu disebut juga keinginan rasional. Hal ini menentukan adanya hubungan konsekuensi antara kehendak dengan pengetahuan sebelumnya.

3. Oleh karena kehendak itu bersifat rasional maka biasanya selalu mengarah kepada nilai kebaikan umum termasuk keinginan yang bersifat parsial. Akibatnya, seseorang tidak pernah menghendaki sesuatu kecuali jika mengandung nilai baik menurut pandangan orang tersebut.

4. Tidak ada hubungan kemestian antara tujuan umum (dalam perbuatanTuhan) dan tujuan parsial (dalam perbuatan manusia), sebaliknya manusia yakin bahwa terdapat ruang perbedaan antara kebaikan transenden dan kebaikan terestial (alam); kebaikan terestial dapat saja bersifat bebas sebagai anugerah dari Yang Maha Baik. 
5. Ketika kehendak itu mengarah kepada suatu objek, dasar ketergantungannya adalah dirinya sendiri. Dengan demikian, ruang lingkup kosmologi tentang objek yang bergerak dan diam, wujud pasif dan aktif adalah mencakup pengertian tentang pengaruh yang sangat menentukan dari kekuatan manusia terhadap perbuatannya sendiri. 7

Jadi perbuatan manusia menurut paham Qadariyah adalah manusia mempunyai kebebasan untuk memilih, dalam hal memilih perbuatan yang baik dan buruk, sebab Allah telah menciptakan keduanya. Jika manusia berbuat baik maka ia akan mendapatkan pahala karena telah mempergunakan kodrat yang diberikan oleh Allah dengan sebaik-baiknya dan sebaliknya.

Adapun ciri-ciri corak pemikiran paham Qadariyah adalah:

1. Kedudukan akal lebih tinggi.

2. Kebebasan manusia dalam kemauan dan perbuatan.

3. Percaya adanya sunnatullah dan kausalitas.

4. Kebebasan berpikir hanya diikat oleh ajaran-ajaran dasar dalam Alquran dan hadis

5. Mengambil metaforis dari wahyu

6. Dinamika dalam sikap dan berpikir. ${ }^{8}$

Qadariyah sangat menghargai akal dengan member porsi sangat besar dalam berpikir sehingga manusia diberi kebebasan dalam berkeinginan dan berbuat. Kebebasan berpikir sangat dijunjung tinggi, tetapi tetap berdasar pada Alquran dan Sunnah Rasulullah saw.

\section{Pendidikan Islam dalam Pandangan Qadariyah}

Telah dijelaskan sebelumnya bahwa Qadariyah adalah paham yang lebih condong kepada penggunaan akal pikiran yang sangat dominan, sehingga menganggap bahwa perbuatan yang dihasilkan manusia itu atas dasar kehendaknya sendiri tanpa adanya campur tangan Tuhan.

Sejalan dengan hal tersebut mengenai pendidikan Islam, seorang tokoh filosof muslim bernama Ibnu Sina mengatakan bahwa seorang anak telah mempunyai kemampuan-kemampuan alamiah, akan tetapi mengandalkan kemampuan tersebut tidak cukup untuk mendidik seseorang, harus ada faktor-faktor lain yang turut mempengaruhinya. Ini berarti bahwa manusia diberikan kebebasan dengan menggunakan akal pikirannya dalam menentukan jalan hidupnya. ${ }^{9}$

Jadi, paham Qadariyah memberikan peran yang sangat besar kepada manusia dalam memilih, berpikir, menentukan atau memutuskan perbuatannnya. Kebebasan yang dimaksud bukan berarti kebebasan tak terbatas, melainkan kebebasan dalam determinisme. Di sinilah peran pendidikan Islam dalam mengajarkan berbagai hal agar menjadi suatu kebiasaan yang tentunya dalam hal ini faktor lingkungan sosial dapat memberikan pengaruh pada kebebasan diri atau pikiran manusia dalam memilih atau memperbuat sesuatu. ${ }^{10}$

Faktor lingkungan pendidikan Islam berfungsi menunjang terjadinya kegiatan proses pembelajaran secara aman, tertib, dan berkelanjutan. Salah satu lingkungan yang berperan adalah lingkungan masyarakat. Manusia adalah makhluk yang dicip- 
takan Allah swt. yang keberadaan hidupnya tidak dapat menyendiri. Manusia membutuhkan masyarakat untuk meningkatkan kualitas hidupnya. Kebutuhan manusia yang diperlukan dari lingkungan masyarakatnya tidak hanya yang menyangkut bidang material melainkan juga bidang spiritual, termasuk ilmu pengetahuan, pengalaman, keterampilan dan sebagainya. Dengan demikian, dapat dipahami bahwa dalam rangka memenuhi kebutuhan pendidikan manusia membutuhkan adanya lingkungan sosial masyarakat. ${ }^{11}$ Masyarakat yang dimaksud adalah masyarakat yang terbuka dan dapat menerima yang baik dari manapun datangnya, tanpa terlepas dari ruh Ilahiyah. Masyarakat muslim juga adalah masyarakat yang kuat fisik dan mentalnya. ${ }^{12}$

Dengan demikian, pendidikan Islam sangat membuka peluang kepada manusia agar senantiasa berusaha mananamkan nilai-nilai yang baik dalam kehidupannya dengan mengerahkan seluruh kemampuan akalnya dan pemahamannya terhadap wahyu (ruh ilahiyah), karena dua hal tersebut selalu berdampingan satu sama lain dan saling melengkapi.

\section{Pendidikan Islam dalam Pandangan Jabariyah}

\section{Latar Belakang Munculnya Paham Jabariyah serta Corak Pemikirannya}

Paham Jabariyah dalam sejarah teologi Islam pertama kali dikemukakan oleh alJa'd bin Dirham. Tetapi yang menyebarkannya adalah Jahm bin Safwan. Jahm bin Safwan adalah tokoh yang paling terkenal sebagai pelopor atau pendiri paham Jabariyah. Paham ini juga identik dengan paham Jahmiyah dalam kalangan Murji'ah sesuai dengan namanya. ${ }^{13}$ Jahm bin Safwan terkenal pandai berbicara dan berpidato menyeru manusia ke jalan Allah dan berbakti kepada-Nya sehingga banyak sekali orang yang tertarik kepadanya. ${ }^{14}$

Adapun corak pemikiran paham Jabariyah menganggap bahwa perbuatan manusia dilakukan oleh Tuhan dan manusia hanya menerima. Hal ini juga dikenal dengan istilah kasb yang secara literal berarti usaha. Tetapi kasb di sini mengandung pengertian bahwa pelaku perbuatan manusia adalah Tuhan sendiri dan usaha manusia tidaklah efektif. Manusia hanya menerima perbuatan bagaikan gerak tak sadar yang dialaminya. ${ }^{15}$ Menurut paham ini bahwa perbuatan manusia mesti ada pelakunya secara hakiki, karena perbuatan membutuhkan adanya pelaku jika manusia bukan pelaku secara hakiki maka tentu Tuhan pelaku secara hakiki (bukan secara majazi).

Ada dua kelompok yang terdapat dalam paham Jabariyah, yaitu Jabariyah murni dan Jabariyah moderat. Jabariyah murni menolak adanya perbuatan yang berasal dari manusia dan memandang menusia tidak mempunyai kemampuan untuk berbuat. Adapun Jabariyah moderat mengakui adanya perbuatan dari manusia namun perbuatannya tidak membatasi. ${ }^{16}$

Dengan demikian, dapat dipahami bahwa Jabariyah menempatkan akal pada porsi yang rendah karena semua tindakan dan ketentuan alam di bawah kekuasaan atau kehendak Tuhan. Sehingga membuat pemikiran dalam segala aspek kehidupan tidak berkembang, bahkan terhenti. Pemikiran diikat oleh dogma, tidak berkembang 
dan mempersempit wawasan yang mengakibatkan tidak adanya pemikiran yang mendalam seperti yang dikehendaki oleh filsafat. Salah satu argumen yang memperkuat paham Jabariyah adalah QS Ash-Shaffat/37: 96.

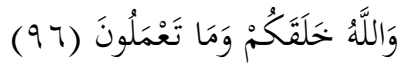

Padahal Allah-lah yang menciptakan kamu dan apa yang kamu perbuat itu. ${ }^{17}$

Harun Nasution menetapkan beberapa ciri paham Jabariyah antara lain:

a. Kedudukan akal rendah

b. Ketidakbiasaan manusia dalam kemauan dan perbuatan

c. Kebebasan berpikir yang diikat oleh dogma

d. Ketidakpercayaan kepada sunnatullah dan kausalitas

e. Terikat pada arti tekstual al-Qur'an dan hadis

f. Statis dalam sikap dan perbuatan. 18

Berdasarkan ciri-ciri tersebut dapat dipahami bahwa paham ini lebih menekankan perbuatan manusia atas kehendak Tuhan, sehingga manusia bagaikan benda yang hanya mengikuti gerakan orang yang menggerakkannya. Kebebasan manusia sangat dibatasi dengan kehendak mutlak Tuhan.

\section{Pendidikan Islam dalam Pandangan Jabariyah}

Sebagaimana telah dijelaskan bahwa Jabariyah adalah paham yang menganggap bahwa segala perbuatan manusia tunduk pada kehendak Tuhan semata. Dengan demikian jika dikaitkan dengan pendidikan Islam maka pendidikan sama sekali tidak mempunyai daya atau kekuatan untuk mempengaruhi anak. Pendidikan hanya dapat memberi polesan luar dari tingkah laku sosial anak, sedangkan bagian internal dari kepribadian anak didik tidak dapat ditentukan, sehingga akan melahirkan sikap pesimisme karena tidak adanya kepercayaan akan nilai-nilai dari pendidikan sehingga anak itu diterima apa adanya. ${ }^{19}$

Di samping itu, dalam Islam juga dikenal dengan teori fitrah yang salah satunya dapat diartikan sebagai potensi dasar dimiliki oleh manusia. Dalam salah satu hadis, Nabi saw. bersabda:

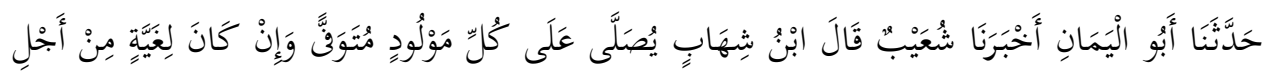

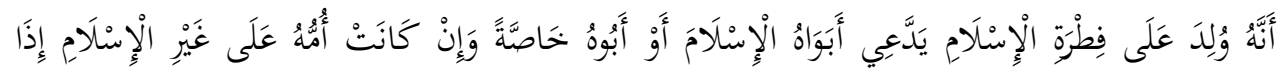

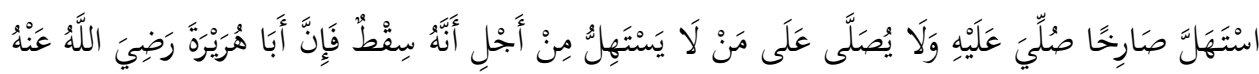

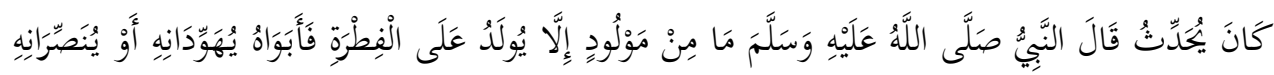

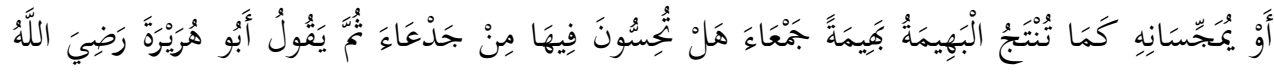

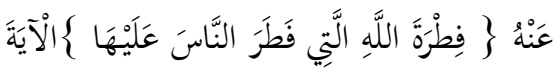

Telah menceritakan kepada kami Abu Al Yaman telah mengabarkan kepada kami Syu'aib berkata, Ibnu Syihab: "Setiap anak yang wafat wajib dishalatkan sekalipun anak hasil zina karena dia dilahirkan dalam keadaan fithrah Islam, jika kedua orangnya mengaku beragama Islam atau hanya bapaknya yang mengaku 
beragama Islam meskipun ibunya tidak beragama Islam selama anak itu ketika dilahirkan mengeluarkan suara (menangis) dan tidak dishalatkan bila ketika dilahirkan anak itu tidak sempat mengeluarkan suara (menangis) karena dianggap keguguran sebelum sempurna, berdasarkan perkataan Abu Hurairah radliallahu 'anhu yang menceritakan bahwa Nabi Shallallahu'alaihiwasallam bersabda: "Tidak ada seorang anakpun yang terlahir kecuali dia dilahirkan dalam keadaan fitrah. Maka kemudian kedua orang tuanyalah yang akan menjadikan anak itu menjadi Yahudi, Nashrani atau Majusi sebagaimana binatang ternak yang melahirkan binatang ternak dengan sempurna. Apakah kalian melihat ada cacat padanya?". Kemudian Abu Hurairah radliallahu 'anhu berkata, (mengutip firman Allah QS Ar-Ruum: 30 yang artinya: ('Sebagai fitrah Allah yang telah menciptakan manusia menurut fitrah itu"20

Bila diinterpretasikan lebih lanjut dari istilah fitrah sebagaimana yang telah disebutkan di atas, dapat mengandung implikasi kependidikan yang berkonotasi kepada paham nativisme. Oleh karena itu, fitrah mengandung makna "kejadian" yang di dalamnya berisi potensi dasar beragama yang benar dan lurus, yaitu Islam. Potensi dasar ini tidak dapat diubah oleh apa pun karena fitrah itu merupakan ciptaan Allah yang tidak akan mengalami perubahan, baik isi maupun bentuknya dalam tiap pribadi manusia.

\section{Pendidikan Islam dalam Pandangan Asy'ariyah}

\section{Latar Belakang Munculnya Paham Asy'ariyah serta Corak Pemikirannya}

Dalam suasana kemuktazilahan yang keruh, muncullah al-Asy'ari, dibesarkan dan didik serta berguru pada al-Jubbai, seorang tokoh Muktazilah sampai mencapai umur lanjut. Ia telah membela aliran Muktazilah sebaik-baiknya. Akan tetapi aliran tersebut kemudian ditinggalkannya bahkan memberinya pukulan-pukulan hebat dan menganggapnya lawan yang berbahaya. ${ }^{21}$

Sebab utama ia meninggalkan aliran Muktazilah karena terjadinya perpecahan antara kaum muslimin yang dapat menghancurkan mereka kalau tidak segera diakhiri, ia sangat mengkhawatirkan Qur'an dan hadis menjadi korban paham-paham Muktazilah, yang menurut pendapatnya tidak dapat dibenarkan karena didasarkan atas pemujaan akal pikiran. Sebagaimana juga dikhawatirkan menjadi korban sikap ahli hadis antrhopomorphis yang hanya memegangi nash-nash dengan meninggalkan jiwanya dan hampir menyeret Islam kepada kelemahan, kebekuan yang tidak dapat dibenarkan agama. 22

Oleh karena itu, Asy'ariyah mengambil jalan tengah antara golongan rasionalis dan golongan tekstualis, ternyata jalan tersebut dapat diterima oleh mayoritas kaum muslimin.

Adapun corak pemikiran Asy'ariyah mengenai perbuatan manusia hubungannya dengan kehendak dan kekuasaan Tuhan ia namai dengan istilah kasb (perolehan/perbuatan). Menurutnya, kasb adalah ciptaan Allah. Dapat disimpulkan bahwa Tuhan pencipta semua perkara manusia berarti Tuhanlah pembuat semuanya pula. Perbuatan yang timbul dari manusia dengan perantaraan daya yang diciptakan adalah berarti manusia sebenarnya merupakan tempat bagi perbuatan Tuhan. 
Oleh karena itu, tampak bahwa tidak terdapat perbedaan-perbedaan antara perbuatan gerakan terpaksa dengan $k a s b$ manusia. Kedua jenis perbuatan tersebut dibuat oleh Tuhan. ${ }^{23}$ Dengan begitu, tampak jelas bahwa manusia sangat dekat dengan paham predestination. Mereka tidak mempunyai kekuasaan atas semua perbuatannya karena Allah pencipta atau pembuat yang sebenarnya. Jadi,pada dasarnya, sesuatu yang dikehendaki oleh Allah akan terjadi sedang sesuatu yang tidak dikehendakiNya tidak akan terjadi.

Dalam pemakaian akal, Asy'ariyah menggunakannya secara seimbang dengan wahyu, tidak berlebihan seperti halnya Muktazilah. Namun, tampaknya ia lebih memprioritaskan wahyu ketimbang akal. Dalam mengomentari empat masalah; mengetahui Tuhan, kewajiban mengetahui Tuhan, mengetauhi baik dan jahat dan kewajiban mengetahui baik dan jahat. Hanya satu yang dapat diketahui akal, yaitu mengetahui Tuhan. Tiga hal lainnya hanya dapat diketahui melalui informasi wahyu.

\section{Pendidikan Islam dalam Pandangan Asy'ariyah.}

Asy'ariyah sebagaimana telah dijelaskan terdahulu bahwa ia merupakan paham sebagai lanjutan dari Jabariyah, hanya saja ia mengambil jalan tengah antara golongan rasionalis dan golongan tekstualis. Tidak menjauhkan diri dari pemakaian akal pikiran dan argumentasi pikiran yang tugasnya tidak lebih dari memperkuat nashnash Alquran dan hadis.

Jika dikaitkan dengan pandangannya mengenai pendidikan Islam maka manusia sesuai dengan teori kasbnya bahwa manusia dapat berkehendak untuk melaksanakan proses pendidikan Islam, adapun mengenai berhasil atau tidaknya proses tersebut maka Tuhanlah yang berkuasa menentukannya, sebab manusia hanya dapat berkehendak akan tetapi Tuhanlah yang menciptakan kehendak yang ada pada diri manusia tersebut. Pandangan ini dalam pendidikan Islam dikenal dengan aliran antara al-fitrah dengan al-bi'ah. ${ }^{24}$ Masing-masing mempunyai peran aktif dalam memberikan pengaruh terhadap proses pendidikan.

Salah seorang tokoh Muslim, Imam al-Ghazali memiliki pandangan yang memadukan antara fitrah dan al-bi'ah sebagaimana yang dianut oleh paham Asy'ariyah. Dia berpendapat bahwa anak itu laksana mutiara yang sangat berharga, murni dan bersih. Apabila anak menerima ajaran dan kebiasaan yang baik, maka anak itu menjadi baik. Sebaliknya jika anak itu dibiasakan dengan melakukan perbuatan buruk dan dibiasakan kepada hal-hal yang jahat, maka anak itu berakhlak buruk. ${ }^{25}$

Paham Asy'ariyah memadukan fitrah yang diberikan Allah kepada manusia sejak dilahirkan ke dunia dengan faktor lingkungan pendidikan yang ditempatinya tumbuh dan berkembang.

\section{SIMPULAN}

Dari uraian di atas, penulis menarik beberapa kesimpulan sebagai berikut:

1. Paham Qadariyah memandang proses pendidikan Islam dapat berlangsung dengan baik jika manusia bersungguh-sungguh berusaha dalam menanamkan nilai-nilai 
islami dalam kehidupannya. Paham ini memandang bahwa perbuatan manusia ditentukan oleh dirinya sendiri, sehingga apa yang dialami manusia dalam hidupnya adalah hasil dari perbuatannya sendiri.

2. Paham Jabariyah memandang bahwa segala perbuatan yang dihasilkan manusia merupakan manifestasi dari kehendak Tuhan, sehingga dalam pandangannya mengenai pendidikan Islam bahwa proses pendidikan tidak begitu berpengaruh sebab berhasil tidaknya sebuah proses pendidikan tersebut akan ditentukan oleh Allah.

3. Paham Asy'ariyah memandang pendidikan Islam merupakan proses yang dinamis, dalam artian manusia di samping telah memiliki potensi dasar untuk menerima proses pendidikan ia juga bergantung pada lingkungan sekitar yang turut mempengaruhi kepribadian seseorang. Meskipun paham ini lebih meyakini bahwa apapun hasil dari proses pendidikan Islam itu adalah tidak lain dari kehendak Tuhan, manusia hanya tunduk pada kehendak tersebut.

\section{CATATAN AKHIR}

1. Khaeruddin, Ilmu Pendidikan Islam, Cet. II; Makassar: Yayasan Pendidikan Fatiya Makassar, 2004, h. 1.

2. Departemen Agama Republik Indonesia, Al-Qur'an dan Terjemahnya, Cet. I; Jakarta: Toha Putra, 1996, h. 793.

3. Lihat: Muhammad Ali Al-Shabuny, Tafsir Ayat Al-Ahkam min al-Qur'an, jilid II; Makkah alMukarramah:Kulliyah al-Syarī'ah wa al-Dirāsah al-Islāmiyah, t.th., h. 538-539.

4. Ibid., h. 2.

5. Agama Islam adalah suati suprasistem yang mengandung: sistem akidah atau keimanan dan keyakinan, sistem syariat, yaitu sistem nilai dan norma yang mengandung ketentuanketentuan, perundang-perundangan, peraturan, bimbingan, ajaran dan informasi; akhlak atau pola perilaku yang didasarkan pada suatu sistem nilai dan norma agama Islam serta proses pembentukan ide atau konsep berpikir yang dapat melahirkan bentuk-bentuk pola keyakinan, interaksi dan bentuk-bentuk institusi sosial tertentu maupun karya budaya yang bersifat material dan konseptual. Lihat: Abuddin Nata, Filsafat Pendidikan Islam, Cet. I; Jakarta: Gaya Media Pratama, 2005, h. 54.

6. Zakiah Daradjat, et al., Ilmu Pendidikan Islam, Cet. VIII; Jakarta: Bumi Aksara, 2009, h. 29.

7. Lihat Hamka Haq, Faslsafat Ushul Fiqh, Makassar: Yayasan al-Ahkam, 2003, h. 164.

8. Harun Nasution, Islam Rasional Gagasan dan Pemikiran, Cet. IV; Bandung: Mizan, 1996, h. 112.

9. Azyumardi Azra, Esei-esei Intelektual Muslim dan Pendidikan Islam, Cet. I; Jakarta: Logos Wacana Ilmu, 1999, h. 82.

10. Jalaluddin Rahman, Konsep Perbuatan Manusia Menurut Qur'an, Cet. I; Jakarta: Bulan Bintang, 1992, h. 91.

11. Abuddin Nata, op. cit., h. 172

12. Ramayulis dan Samsul Nizar, Filsafat Pendidikan Islam: Telaah Sistem Pendidikan dan Pemikiran Para Tokohnya, Cet. II; Jakarta: Kalam Mulia, 2005, h. 71.

13. Harun Nasution, op. cit., h. 33.

14. Ahmad Amin, Fajr al-Islam, Kairo: Dar al-Kutub al-'Arabiyah, 1996, h. 454.

15. Hamka Haq, op. cit., h. 161. 
16. Asy-Syahrastani, al-Milal wa al-Nihal diterjemahkan oleh Asywadie Syukur, Surabaya: PT.Bina Ilmu, t.th, h. 71.

17. Departemen Agama RI., Al-Qur'an dan Terjemahnya, Semarang: Toha Putra, 2007, h. 640.

18. Harun Nasution, op. cit., h. 116.

19. Khaeruddin, op. cit., h. 63.

20. Imām Abū 'Abdullah Muhammad bin Isma'îl ibn Ibrāhīm bin Mughīrah bin Bardizbah alBukhāry al-Ja'fiy, Shahìh al-Bukhāri, juz III, Bairūt: Dār al-Kutub al-Ilmiah, 1992, h. 69

21. Ahmad Hanafi, Teologi Islam (Ilmu Kalam), Cet. XII; Jakarta: Bulan Bintang, 2001, h. 65.

22. Ibid., h. 66.

23. Jalaluddin Rahman, op. cit., h. 87.

24. Khaeruddin, op. cit., h. 68.

25. Abuddin Nata, op. cit., h. 212

\section{DAFTAR PUSTAKA}

Amin, Ahmad. Fajr al-Islam. Kairo: Dar al-Kutub al-'Arabiyah, 1996.

Azra, Azyumardi. Esei-esei Intelektual Muslim dan Pendidikan Islam. Cet. I; Jakarta: Logos Wacana Ilmu, 1999.

al-Bukhāry, Imām Abū 'Abdullah Muhammad bin Isma'îl ibn Ibrāhīm bin Mughīrah bin Bardizbah. Shahìh al-Bukhāri. juz III. Bairūt: Dār al-Kutub al-Ilmiah, 1992 .

Daradjat, Zakiah, et al. Ilmu Pendidikan Islam. Cet. VIII; Jakarta: Bumi Aksara, 2009.

Departemen Agama RI. Al-Qur'an dan Terjemahnya. Semarang: Toha Putra, 2007.

Hanafi, Ahmad. Teologi Islam (Ilmu Kalam). Cet. XII; Jakarta: Bulan Bintang, 2001.

Haq, Hamka. Faslsafat Ushul Fiqh. Makassar: Yayasan al-Ahkam, 2003.

Khaeruddin. Ilmu Pendidikan Islam. Cet. II; Makassar: Yayasan Pendidikan Fatiya Makassar, 2004.

Nasution, Harun. Islam Rasional Gagasan dan Pemikiran. Cet. IV; Bandung: Mizan, 1996.

Nata, Abuddin. Filsafat Pendidikan Islam. Cet. I; Jakarta: Gaya Media Pratama, 2005.

Rahman, Jalaluddin. Konsep Perbuatan Manusia Menurut Qur'an. Cet. I; Jakarta: Bulan Bintang, 1992.

Ramayulis dan Samsul Nizar. Filsafat Pendidikan Islam: Telaah Sistem Pendidikan dan Pemikiran Para Tokohnya. Cet. II; Jakarta: Kalam Mulia, 2005.

al-Shabuny, Muhammad Ali. Tafsir Ayat Al-Ahkam min al-Qur'an, jilid II. Makkah al-Mukarramah:Kulliyah al-Syarī'ah wa al-Dirāsah al-Islāmiyah, t.th.

al-Syahrastani. al-Milāl wa al-Nihāl. Diterjemahkan oleh Asywadie Syukur, Surabaya: PT.Bina Ilmu, t.th. 